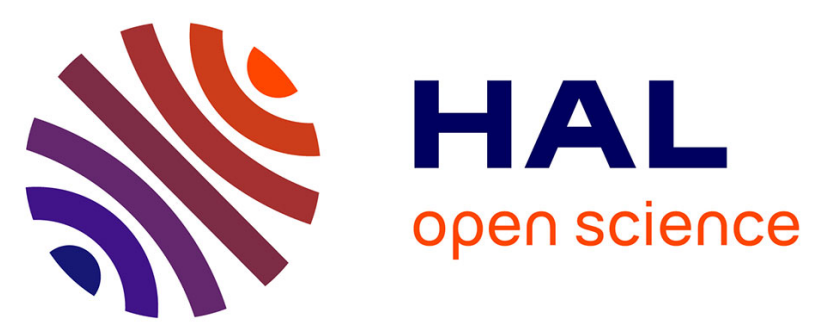

\title{
Lactococcus lactis strains from raw ewe's milk samples from the PDO Ossau-Iraty cheese area: levels, genotypic and technological diversity
}

Fabienne Feutry, Paloma Torre, Ines Arana, Susana Garcia, Nathalie N. Desmasures, Erick Casalta

\section{To cite this version:}

Fabienne Feutry, Paloma Torre, Ines Arana, Susana Garcia, Nathalie N. Desmasures, et al.. Lactococcus lactis strains from raw ewe's milk samples from the PDO Ossau-Iraty cheese area: levels, genotypic and technological diversity. Dairy Science \& Technology, 2012, 92 (6), pp.655-670. 10.1007/s13594012-0084-3 . hal-00930649

\section{HAL Id: hal-00930649 \\ https://hal.science/hal-00930649}

Submitted on 1 Jan 2012

HAL is a multi-disciplinary open access archive for the deposit and dissemination of scientific research documents, whether they are published or not. The documents may come from teaching and research institutions in France or abroad, or from public or private research centers.
L'archive ouverte pluridisciplinaire HAL, est destinée au dépôt et à la diffusion de documents scientifiques de niveau recherche, publiés ou non, émanant des établissements d'enseignement et de recherche français ou étrangers, des laboratoires publics ou privés.

$$
\text { Copyright }
$$




\title{
Lactococcus lactis strains from raw ewe's milk samples from the PDO Ossau-Iraty cheese area: levels, genotypic and technological diversity
}

\author{
Fabienne Feutry • Paloma Torre • Ines Arana • Susana Garcia • \\ Nathalie Desmasures • Erick Casalta
}

Received: 4 February 2012 / Revised: 8 July 2012 / Accepted: 16 July 2012 /

Published online: 30 August 2012

C) INRA and Springer-Verlag, France 2012

\begin{abstract}
The aims of this work were to assess the levels of Lactococcus lactis (L. lactis) in ewe's milk produced in three Ossau-Iraty cheese sub-areas and to investigate the genotypic and technological diversity of isolated wild strains of L. lactis in order to assess their suitability for use as components of starter formulations. Thirty-two milk samples from 32 farms were collected. Strains of $L$. lactis were identified and quantified using a combination of species and subspecies-specific polymerase chain reaction (PCR) and PCR amplification of repetitive bacterial DNA elements (Rep-PCR). The genotypic and technological diversity of the indigenous strains was compared to that of 12 commercial strains. $L$. lactis was detected in milk samples from only 20 farms. The levels detected were below $4 \log _{10}$ cfu. $\mathrm{mL}^{-1}$ in $75 \%$ of the milks. L. lactis subsp. lactis dominated in $66 \%$ of the samples. Forty-three genotypic profiles of wild $L$. lactis strains were detected and showed greater diversity than those of the commercial strains. Milks containing $L$. lactis contained one to four distinct strains. With the exception of two strains, each strain was found in milk from only one farm. The $\mathrm{Prt}^{+}$strains were the most acidifying. Sensitivity to phages collected from wheys differed widely between the commercial $(60 \%)$ and indigenous strains $(5 \%)$. Wild strains of $L$. lactis displayed a wide genotypic and technological diversity. Genotypic diversity seemed to be linked to the farm of origin. This study addresses questions regarding the environmental factors which influence such natural diversity. A deeper knowledge of the strain-dependent technological properties would be useful in selecting strains for use in starter blends.
\end{abstract}

\footnotetext{
F. Feutry $(\bowtie)$

Syndicat de défense de l'AOC Ossau-Iraty, 64120 Ostabat-Asme, France

e-mail: syndicat.ossau-iraty@wanadoo.fr

P. Torre $\cdot$ I. Arana $\cdot$ S. Garcia

Area de Nutrición y Bromatología, Departamento de Ciencias del Medio Natural, Universidad Pública de Navarra, Campus Arrosadía s/n, 31006 Pamplona, Navarra, Spain

\author{
N. Desmasures \\ IFR146 ICORE, Esplanade de la paix, Université de Caen Basse Normandie, E.A. 4651, Aliments, \\ Bioprocédés, Toxicologie, Environnements, 14032 CAEN cedex, France \\ E. Casalta \\ INRA, UMR1083 Sciences pour l'œnologie, 2, place Viala, 34060 Montpellier Cedex 1, France
}




\section{Ossau-Iraty 原产地名号保护干酪生产地区生鲜羊乳中乳酸乳球菌的含量, 基因型和特性}

摘要: 本文目的是评价Ossau-Iraty原产地名号保护 (PDO) 干酪生产地区生鲜羊 乳乳酸乳球菌的含量以及分离的野生乳酸乳球菌的基因型和多样性, 以及这些 乳酸菌作为发酵剂的可行性. 32 个乳样分别来自 32 个农场. 采用物种和亚种特 异性聚合酶链反应(PCR)和重复细菌DNA元素PCR扩增相结合的方法来分析和鉴 定乳酸乳球菌. 将分离菌株的基因型和技术特性与 12 株商业菌株进行了比较, 仅从 20 个农场的羊乳样本中检测到乳酸乳球菌. $75 \%$ 的乳样中乳酸乳球菌的含 量低于4 log cfu $\mathrm{mL}^{-1}$, 乳酸乳球菌乳酸亚种在样品中占 $66 \%$. 野生乳酸乳球菌中 检测出 43 种基因型, 与商业菌株相比, 野生乳酸乳球菌更具有多样性. 乳酸乳 球菌中含有 14 株特殊的菌株. 除2株菌外, 每个农场的羊奶样品中都能够检 测到不同于其他农场的特有菌株. 从乳清中收集的噬菌体与商业菌株和本土 菌株比较存在较大的差异. 蛋白酶阳性 $(\operatorname{Prt}+)$ 菌株的酸化能力最强. 野生乳 酸乳球菌显示了较广的基因型和多样性. 基因多样性似乎与农场有关. 本研究 进一步说明了环境因素是影响菌株固有多样性的主要因素. 对菌株技术特性的 深入研究将有助于混合发酵剂菌株的篮选.

Keywords Lactococcus lactis · Wild strain · Diversity · Technological · Genotypic · Ewe's milk

关键词 乳酸乳球菌·野生菌株·多样性·技术的·基因型·羊奶

\section{Introduction}

The species Lactococcus lactis has been classified as having the generally recognized as safe (GRAS) status (Casalta and Montel 2008). The ability to rapidly produce $\mathrm{L}(+)$ lactic acid is probably the most important property of this species, and explains their widespread use in the manufacture of many cheese varieties. Two main phenotypically defined subspecies of L. lactis are used intensively as dairy starters, namely Lactococcus lactis subsp. lactis (plus a diacetyl-forming biovariety, L. lactis subsp. lactis biovar diacetylactis) and Lactococcus lactis subsp. cremoris. The distinction between $L$. lactis subsp. lactis and L. lactis subsp. cremoris is based on a set of phenotypic characteristics (ability to grow at $40{ }^{\circ} \mathrm{C}$, in $4 \% \mathrm{NaCl}$ and at $\mathrm{pH} 9.2$, ability to ferment maltose and capacity to deaminate arginine) and is of great technological interest, but this distinction may be erroneous as it may vary among strains and hence is very strain dependent (Fernández et al. 2011). As a consequence, various DNA-based techniques such as random amplified polymorphic DNA, pulse-field gel electrophoresis, repetitive sequence-based PCR (Rep-PCR), amplified fragment length polymorphism, multilocus sequence analysis, and restriction fragment length polymorphism have been used to distinguish L. lactis at subspecies and strain levels (Taïbi et al. 2010).

Ossau-Iraty cheese is one of two French PDO ewe's milk cheeses. It is a ripened, uncooked pressed ewe's milk cheese produced in the southwestern region of France, in a limited geographic area which includes the Bearn and the Basque Country. It is made from raw or pasteurized milk and coagulated with rennet. Ossau-Iraty cheese-makers are allowed to use commercial lactic starters, mainly composed of strains of L. lactis, to ensure regular, efficient acidification. 
Over the past two decades there has been an increasing interest in screening lactococci from natural dairy products in order to isolate strains with improved or novel properties for their potential application in the manufacture of traditional products. These studies have highlighted the wide diversity which exists among wild strains, much greater than among commercial or reference strains (Sánchez et al. 2000). Strain diversity can produce a wide range of genotypic profiles (Corroler et al. 1998; Fernández et al. 2011) which are not always consistent with phenotypic profiles at subspecies or strain levels (de la Plaza et al. 2006; Fernández et al. 2011). This diversity can lead to a wide range of technological abilities of individual strains including flavor formation, acidifying activity, production of antimicrobial compounds, and phagic resistance.

Compared to raw cow's milk (Franciosi, et al. 2009), to our knowledge, little data are available on strains of L. lactis isolated from raw ewe's milks (Feutry et al. 2011). Most investigations have focused on the genotypic diversity and/or technological properties of strains of L. lactis isolated only from fresh (Gaya et al. 1999; NietoArribas et al. 2009) or ripened (Nieto-Arribas et al. 2009) ewe's milk cheese. Moreover, to our knowledge, the incidence of the area of production on the diversity of isolates found in raw ewe's milk has not been studied.

Our purpose was to assess the levels of L. lactis in ewe's milk produced in the Ossau-Iraty PDO cheese sub-areas and to investigate the genotypic and technological diversity of strains of isolated wild L. lactis for their potential for use in multi-strain starter formulations.

\section{Materials and methods}

\subsection{Sampling}

Thirty-two dairy farms in three dairy sub-areas A, B, and C (10, 10, and 12 farms, respectively) of the PDO Ossau-Iraty cheese region were selected on the basis of their high-quality raw milk according to the quality criteria set by the milk payment system $\left(\leq 10^{5}\right.$ cfu. $\mathrm{mL}^{-1}$ total viable counts, $\leq 500$ coliforms. $\mathrm{mL}^{-1}, \leq 1,000$ butyric spores. $\mathrm{L}^{-1}$ ). The sub-areas were 25 to $70 \mathrm{~km}$ distant from each other.

One bulk raw milk sample $(50 \mathrm{~mL})$ was collected from each farm, in spring, immediately after first milking. All samples were transported within $4 \mathrm{~h}$ to the laboratory under refrigerated conditions and were stored at $4{ }^{\circ} \mathrm{C}$ until analysis.

The whey samples $(20 \mathrm{~mL})$ were collected from one cheese-making production at 21 farmhouses (W1-W21) located across the Ossau-Iraty cheese area. All samples were transported within $4 \mathrm{~h}$ to the laboratory under refrigerated conditions. They were prepared as described by de Godoy Oriani and Yokoya (2004) and stored at $-80{ }^{\circ} \mathrm{C}$ with $30 \%$ glycerol until use.

\subsection{Isolation of LAB}

Raw milk sample preparation and decimal dilutions were carried out according to the IDF Standard 122C (1996) and samples were plated in duplicate. Standard plate counts were performed using Plate Count Agar medium (PCA, Difco, Spain). Lactococci were isolated from L-M17 agar medium (Callon et al. 2004): M17 agar 
(Difco, France) (Terzaghi and Sandine 1975) containing 2 g.L $\mathrm{L}^{-1}$ lactose, $5 \mathrm{mg} . \mathrm{L}^{-1}$ bromocresol purple, $20 \mathrm{mg} . \mathrm{L}^{-1}$ amphotericyn $\mathrm{B}$, and $40 \mathrm{mg} . \mathrm{L}^{-1}$ nalidixic acid. All media were incubated at $30{ }^{\circ} \mathrm{C}$ for $72 \mathrm{~h}$.

After incubation, a representative number of colonies (at least the square root of the cfu count per plate) were randomly taken from each L-M17 plate and colonies were purified by successive subcultures on the same medium. All isolates were checked for Gram reaction and catalase activity. The Gram-positive and catalase-negative isolates were further studied. Twelve commercial strains of L. lactis from two starters (S1 (five) and S3 (seven)) commonly used in the Ossau-Iraty cheese-making were included in the study (Table 1). All LABs were stored frozen at $-80{ }^{\circ} \mathrm{C}$ in cryotubes (AES, Combourg, France). These frozen stocks were used for further typing and identification.

\subsection{L. lactis screening, genotypic typing, and quantification}

After rapid DNA extraction (Gaya et al. 1999), a first screening of commercial and indigenous LAB isolates were performed by PCR amplification of repetitive bacterial DNA elements (Rep-PCR) as described by Berthier et al. (2001). REP1R-Dt/REP2-D primers were first used to screen L. lactis strains. ERIC1R/ERIC2 primers (Versalovic et al. 1991) were subsequently used to improve the genotypic fingerprinting discrimination of the L. lactis isolates. The reference strains L. lactis subsp. lactis CECT 185T; L. lactis subsp. lactis biovar diacetylactis DSMZ 20661T; and L. lactis subsp. cremoris ATCC 9596, DSMZ 20069T, and ATCC 11603 were used for comparison.

After electrophoresis and gel scan, GelCompar II ${ }^{\circledR}$ software version 4.0 (Applied Maths, Kortrijk, Belgium) was used to calculate the similarity between the band profiles, based on the Pearson correlation coefficient. A dendrogram was deduced from the matrix of similarities using an arithmetic average clustering algorithm (UPGMA: Unweighted Pair Group Method with Arithmetic Averages). Rep-PCR fingerprints with a similarity coefficient $\geq 85 \%$ and visually identical were deemed to be fingerprints of the same strain (Feutry et al. 2011) and permitted representative strains to be designated. Specific PCR reactions (Table 2) was performed with DNA from one representative strain of each Rep-PCR cluster in order to identify the presumed L. lactis subspecies and biovar. When isolates were grouped with a reference strain, specific primers amplifying DNA from that reference strain were first used. The levels of L. lactis in the milks were estimated by multiplying the

Table 1 Lactococcus lactis strains isolated from two commercial starters, S1 and S3, used in Ossau-Iraty cheese manufacture

Commercial starters

\begin{tabular}{lll}
\hline Species and subspecies & S1 & S3 \\
L. lactis subsp. lactis & L1, L8, L14 & L324, L326, L3210 \\
L. lactis subsp. cremoris & C3 & C322, C328, C3212 \\
L. lactis subsp. lactis biovar. diacetylactis & D15 & D5
\end{tabular}

Each strain corresponds to normalized Rep and Eric-PCR profiles analyzed using Pearson's productmoment correlation coefficient and clustered by UPGMA 
Table 2 Specific primer pairs, amplification cycles, and expected size of PCR products

\begin{tabular}{|c|c|c|c|c|c|}
\hline PCR specificity & Primers & Primer sequence $\left(5^{\prime}-3^{\prime}\right)$ & $\begin{array}{l}\text { Amplification } \\
\text { cycle }\end{array}$ & $\begin{array}{l}\text { PCR product } \\
\text { size }(\mathrm{pb})\end{array}$ & Reference \\
\hline \multirow[t]{2}{*}{ L. lactis } & Lla & $\begin{array}{l}\text { CAGTCGGTACAAG } \\
\text { TACCAAC }\end{array}$ & \multirow{2}{*}{$\begin{array}{c}35 \times\left[30 \mathrm{~s} / 94^{\circ} \mathrm{C}\right. \\
45 \mathrm{~s} / 55^{\circ} \mathrm{C} \\
\left.1 \mathrm{~min} / 72^{\circ} \mathrm{C}\right]\end{array}$} & \multirow[t]{2}{*}{87} & \multirow[t]{2}{*}{$\begin{array}{l}\text { Barakat et } \\
\text { al. }(2000)\end{array}$} \\
\hline & $27 f$ & $\begin{array}{l}\text { AGAGTTTGATCMTG } \\
\text { GCTCAG }\end{array}$ & & & \\
\hline \multirow[t]{2}{*}{$\begin{array}{l}\text { L. lactis subsp. } \\
\text { lactis }\end{array}$} & LLhis3F & $\begin{array}{l}\text { AAAGAATTTTCAGA } \\
\text { GAAA }\end{array}$ & \multirow{2}{*}{$\begin{array}{c}30 \times\left[1 \mathrm{~min} / 94{ }^{\circ} \mathrm{C},\right. \\
1 \mathrm{~min} / 58^{\circ} \mathrm{C}, \\
\left.90 \mathrm{~s} / 72^{\circ} \mathrm{C}\right]\end{array}$} & \multirow[t]{2}{*}{343} & \multirow[t]{2}{*}{$\begin{array}{l}\text { Beimfohr et } \\
\text { al. (1997) }\end{array}$} \\
\hline & LLhis4R & $\begin{array}{l}\text { ATTTAGAATTGGTT } \\
\text { CAAC }\end{array}$ & & & \\
\hline \multirow[t]{2}{*}{$\begin{array}{l}\text { L. lactis subsp. } \\
\text { cremoris }\end{array}$} & LLchis1F & $\begin{array}{l}\text { GCGCTGAATTTAC } \\
\text { CTGAC }\end{array}$ & \multirow{2}{*}{$\begin{array}{c}30 \times\left[30 \mathrm{~s} / 94{ }^{\circ} \mathrm{C},\right. \\
1 \mathrm{~min} / 54{ }^{\circ} \mathrm{C} \\
\left.2 \mathrm{~min} / 72^{\circ} \mathrm{C}\right]\end{array}$} & \multirow[t]{2}{*}{556} & \multirow[t]{2}{*}{$\begin{array}{l}\text { Beimfohr et } \\
\text { al. (1997) }\end{array}$} \\
\hline & LLchis2R & $\begin{array}{l}\text { TTCGCGCACCGC } \\
\text { CGTC }\end{array}$ & & & \\
\hline \multirow{2}{*}{$\begin{array}{c}\text { L. lactis subsp. } \\
\text { lactis biovar } \\
\text { diacetylactis }\end{array}$} & Lhis5F & $\begin{array}{l}\text { CTTCGTTATGATT } \\
\text { TTACA }\end{array}$ & \multirow{2}{*}{$\begin{array}{c}30 \times\left[30 \mathrm{~s} / 94{ }^{\circ} \mathrm{C},\right. \\
1 \mathrm{~min} / 46{ }^{\circ} \mathrm{C} \\
\left.2 \mathrm{~min} / 72{ }^{\circ} \mathrm{C}\right]\end{array}$} & \multirow[t]{2}{*}{934} & \multirow[t]{2}{*}{$\begin{array}{l}\text { Beimfohr et } \\
\text { al. (1997) }\end{array}$} \\
\hline & Lhis6R & $\begin{array}{l}\text { AATATCAACAATT } \\
\text { CCATG }\end{array}$ & & & \\
\hline
\end{tabular}

percentage of L-M17 isolates identified as L. lactis by the number of bacteria counted from L-M17 as described by Depouilly et al. (2004). The proportion of each L. lactis subspecies in each sub-area was calculated by dividing the number of isolates of that subspecies by the total number of identified L. lactis isolates. The intraspecies diversity of L. lactis was assessed by dividing the number of genotypic profiles by the total number of identified L. lactis isolates.

\subsection{Technological characterization}

Technological properties were evaluated for one representative autochthonous $L$. lactis strain of each main cluster (see Section 2.3) and for the 12 commercial $L$. lactis strains (see Section 2.2).

\subsubsection{Proteolytic ability assessment}

Although no proteolytic ability was measured, proteolytic ability was assessed by studying the presence of the gene coding for the cell envelope proteinase (Prt). It was detected by specific PCR using the primer set P6: 5'-AACACGGCATGCATGTTGC3'/P7: 5'-CTGGCGTTCCCACCATTCA-3' as described by Klijn et al. (1995). The expected size of the PCR product was $393 \mathrm{bp}$. The reference strain, L. lactis subsp. cremoris DSMZ 4367, was used as positive control.

\subsubsection{Acidifying activity}

The acidifying activity of the strains was evaluated twice by $\mathrm{pH}$ measurements on reconstituted ewe's milk powder (Udipal, Onet-le-Château, France). The milk was 
reconstituted at $10 \%(\mathrm{w} / \mathrm{v})$ with sterile water and then pasteurized at $63{ }^{\circ} \mathrm{C}$ for $30 \mathrm{~min}$. The protocol described by Casalta et al. (1995) was used. Two subcultures of each strain were carried out in pasteurized $\left(118{ }^{\circ} \mathrm{C}, 18 \mathrm{~min}\right)$ skim cow's milk (Difco, Spain) at $30^{\circ} \mathrm{C}$, first for $24 \mathrm{~h}$ and then for $16 \mathrm{~h}$ to reach $10^{9} \mathrm{cfu} \cdot \mathrm{mL}^{-1}$. Two milliliters of this final culture were inoculated into $198 \mathrm{~mL}$ of ewe's milk at $25^{\circ} \mathrm{C}$. The thermal gradient commonly used for making Ossau-Iraty cheese was used to evaluate the behavior of all the tested strains (Fig. 1): the temperature was increased to $30{ }^{\circ} \mathrm{C}$ (in $5 \mathrm{~min}$ ) and kept constant for $1 \mathrm{~h} 30 \mathrm{~min}$ (step 1). Then it was increased progressively $\left(1{ }^{\circ} \mathrm{C} / 2 \mathrm{~min}\right.$ ) to $40{ }^{\circ} \mathrm{C}$ and kept constant for $20 \mathrm{~min}$ (step 2). Heating was then stopped. The temperature decreased gradually to $20^{\circ} \mathrm{C}$ over $24 \mathrm{~h}$, simulating curd settling, molding (step 3), pressing (step 4), and draining (step 5). The $\mathrm{pH}$ and temperature were then measured by electrodes (FC210B, Hanna Instruments, Eibar, Spain) previously washed with a pepsine/ $\mathrm{HCl}$ solution (HI387, Hanna Instruments) and disinfected ( $2 \mathrm{~min}$ in sodium hypochlorite $1 \%$ ). The electrodes were linked to a transmitter/receptor system (Labguard, AES, Combourg, France). The Temperanet 4.1.d Com2 software (AES, Combourg, France) recorded $\mathrm{pH}$ and temperature data at 1-min intervals for $24 \mathrm{~h}$. The $\mathrm{pH}$ differences $(\Delta \mathrm{pH})$ at each step (Fig. 1) were calculated for the presumptive $\mathrm{Prt}^{+}$and $\mathrm{Prt}^{-}$autochthonous strains and for the commercial strains.

\subsubsection{Lysogeny and phage sensitivity}

Strain lysogeny was detected by $\mathrm{P} 335$ prophage investigation using specific primers (P335A： 5'-GAAGCTAGGCGAATCAGTAA-3'/P33 5B：5'-GATTGCCATTTGCGCTCTGA-3') as described by Labrie and Moineau (2000). Expected fragment size was 682 bp. The strain L. lactis ssp. lactis CECT 916 and phage type P335 were used as positive controls.

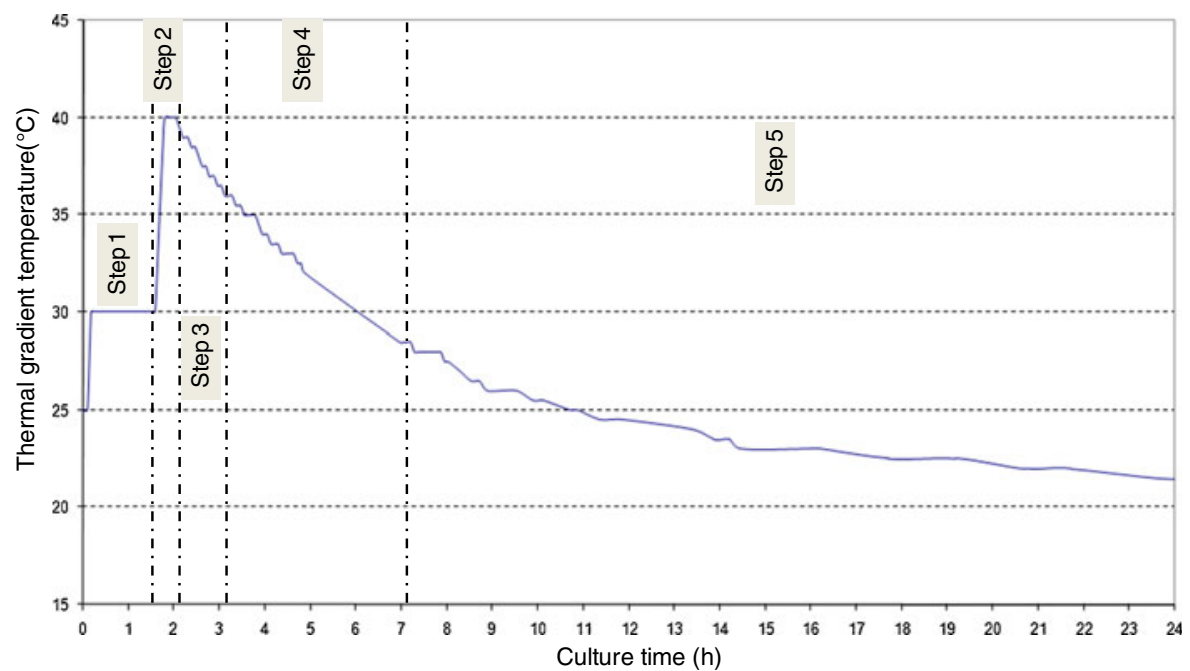

Fig. 1 Thermal gradient used to simulate the Ossau-Iraty cheese process in reconstituted and pasteurized ewe's milk culture. Step 1 addition of starter-renneting-coagulation-cutting (1.5 h; end at 1.6 h). Step 2 heating/stirring ( $40 \mathrm{~min}, 1^{\circ} \mathrm{C} / 2 \mathrm{~min}$; end at $2.3 \mathrm{~h}$ ). Step 3 moulding (50 min; end at $3.1 \mathrm{~h}$ ). Step 4 pressing (4 h; end at $7.1 \mathrm{~h})$. Step 5 draining $(\sim 17 \mathrm{~h}$; end at $24 \mathrm{~h})$ 
Strains were tested twice for phage sensitivity against 23 collection phages (Christian Hansen Laboratorium, Horsholm, Denmark; Oviedo University, Spain) and 21 wheys (W1 to W21) collected from the Ossau-Iraty cheese area and potentially contaminated by phages. The double-layer method (Terzaghi and Sandine 1975) was used: individual strains were mixed with M17 semisolid agar containing $0.2 \% \mathrm{CaCl}_{2}$ and overlaid onto M17 agar plates. Phage and whey preparations were spotted onto the agar and examined for lysis plaques after overnight incubation at $30{ }^{\circ} \mathrm{C}$.

\subsubsection{Compatibility of strains}

To screen for antimicrobial activity, 43 wild strains (each one representative of a genotypic profile; see Section 2.3) which were non-lysogenic and resistant to phages from the collection and wheys (see 2.4.3) were assayed against each other by evaluating the resulting acidification after co-inoculation of two strains in similar proportions. The method described for individual strains was used (see 2.4.2).

\subsection{Statistical analysis}

Statistical analysis consisted of determination of the mean, minimum, maximum, and 75 th percentile values. One-way analysis of variance (ANOVA) was applied to the results of $L$. lactis subspecies counts to evaluate the effect of sub-area. ANOVA was also applied to the $\Delta \mathrm{pH}_{24 \mathrm{~h}}$ and $\Delta \mathrm{pH}(\mathrm{pH} n$ step $-\mathrm{pH} n+1$ step) obtained after each step of the thermal gradient of Ossau-Iraty cheese-making as defined in Fig. 1, to differentiate the strains group according to strain origin and the presence or absence of the Prt gene. For this, the SPSS software package ver. 15.0 (SPSS Inc., Chicago, IL., USA) was used.

\section{Results and discussion}

\subsection{L. lactis presence and levels in ewe's milks}

Five hundred and ninety-three isolates were collected from L-M17 plates. Among them, $392(66 \%)$ were identified as LAB. LABs were detected in all the milks and represented between 10 and $100 \%$ of the isolates collected. Species-specific PCR identified 180 of the 392 LAB as L. lactis. However, despite the systematic presence of LABs and total counts ranging from 4.4 to $5.5 \log _{10}$ cfu.mL $\mathrm{mL}^{-1}$, L. lactis was detected in milk samples from only 20 farms (62\%; Table 3$)$. Where detected, levels of L. lactis were $1 \log _{10}$ lower than the total viable counts. L. lactis levels varied between 1.9 and $5.2 \log _{10}$ cfu.mL $\mathrm{mL}^{-1}$, as observed in other ewe's milks (Casalta et al. 2001). In $75 \%$ of the milks levels did not exceed $3.9 \log _{10}$ cfu.mL $\mathrm{m}^{-1}$.

Contrary to our results, Corroler et al. (1998) detected L. lactis in $100 \%$ of cow's milks. Few studies on ewe's milk allow a comparison with our results to be performed. Feutry et al. (2011) recently observed that L. lactis was only detected in a third of raw ewe's milks at levels of $<2 \log _{10}$ cfu.mL ${ }^{-1}$. In that study, the authors suggested that cold storage of milk $\left(4^{\circ} \mathrm{C}\right.$ for $\left.48 \mathrm{~h}\right)$ might have favored a decrease in lactococci, as suggested by Lafarge et al. (2004). However, Medina et al. (2001) 
Table 3 Distribution of LAB and Lactococcus lactis subspecies in ewe's milks from three Ossau-Iraty cheese production sub-areas (A, B, and C)

\begin{tabular}{|c|c|c|c|}
\hline & \multicolumn{3}{|l|}{ Sub-area } \\
\hline & $A$ & $B$ & $C$ \\
\hline No. of farm & $1-10$ & $11-20$ & $21-32$ \\
\hline Number of milk samples & 10 & 10 & 12 \\
\hline Number of milk samples containing LABs & 10 & 10 & 12 \\
\hline Number of milk samples containing L. lactis $^{\mathrm{a}}$ & 7 & 9 & 4 \\
\hline Total number of isolates & 203 & 208 & 182 \\
\hline Number of LABs isolates from M17L (\%) & $107(52.7)$ & $149(71.6)$ & $111(61.0)$ \\
\hline Number of L. lactis isolated from M17L (\%) & $49(24.1)$ & $82(39.4)$ & $49(26.9)$ \\
\hline Number of subsp. lactis isolates ( $\%$ over total number of $L$. lactis) & $43(87.8)$ & $57(69.5)$ & $19(38.8)$ \\
\hline Number of subsp. cremoris isolates ( $\%$ over total number of $L$. lactis) & ) $6(12.2)$ & $25(30.5)$ & $30(61.2)$ \\
\hline Total viable counts $\left(\log _{10}\right.$ cfu.mL $\left.L^{-1} \pm \mathrm{SD}\right)$ & $4.4 \pm 0$ & $5.5 \pm 0$ & $5.2 \pm 0.6$ \\
\hline \multicolumn{4}{|l|}{ L. lactis counts $\left(\log _{10} \mathrm{cfu} / \mathrm{mL}^{-1}\right)^{\mathrm{a}}$} \\
\hline Mean & 3.6 & 4.3 & 4.4 \\
\hline Minimum & 1.9 & 2.0 & 3.0 \\
\hline Maximum & 4.0 & 5.2 & 4.8 \\
\hline 75th percentile & 3.8 & 3.9 & 4.5 \\
\hline Number of L. lactis subsp. lactis genotypic profiles (see Fig. 2) & 14 & 8 & 4 \\
\hline Number of L. lactis subsp. cremoris genotypic profiles (see Fig. 2) & 5 & 8 & 5 \\
\hline
\end{tabular}

${ }^{\text {a }}$ Confirmed by specific PCR

showed, by phenotypic identification methods, that lactobacilli and enterococci dominated in Argentinean ewe's milks. Those studies also found that lactococci were not systematically present in ewe's milk.

Among the L. lactis identified, the genotype of subspecies lactis was represented twice as often (119 isolates, 66\%) as the cremoris genotype (61 isolates, 34\%). Moreover, in 10 milk samples, only the lactis genotype was detected. No isolate belonging to the diacetylactis biovar. was identified. Feutry et al. (2011) also found no diacetylactis biovar in ewe's milk samples. The dominance of the L. lactis subsp. lactis genotype has also been reported in raw cow's milk (Desmasures et al. 1998) and from fresh ewe's cheeses (Gaya et al. 1999). The L. lactis subsp. lactis biovar diacetylactis genotype has been identified in fresh ewe's cheeses (Gaya et al. 1999). Regarding the proportion of cremoris genotype in this study, it was comparable to that obtained by Desmasures et al. (1998) from cow's milk samples, with the cremoris genotype representing $37.5 \%$ of the isolates.

\subsection{Genotypic diversity of strains of L. lactis}

The combination of the two fingerprints generated by the REP1R-Dt/REP2-D and ERIC1R/ERIC2 primers grouped the 180 autochthonous L. lactis strains in 43 profiles of which 26 were L. lactis subsp. lactis (Fig. 2a) and 17 were L. lactis subsp. cremoris (Fig. 2b). 


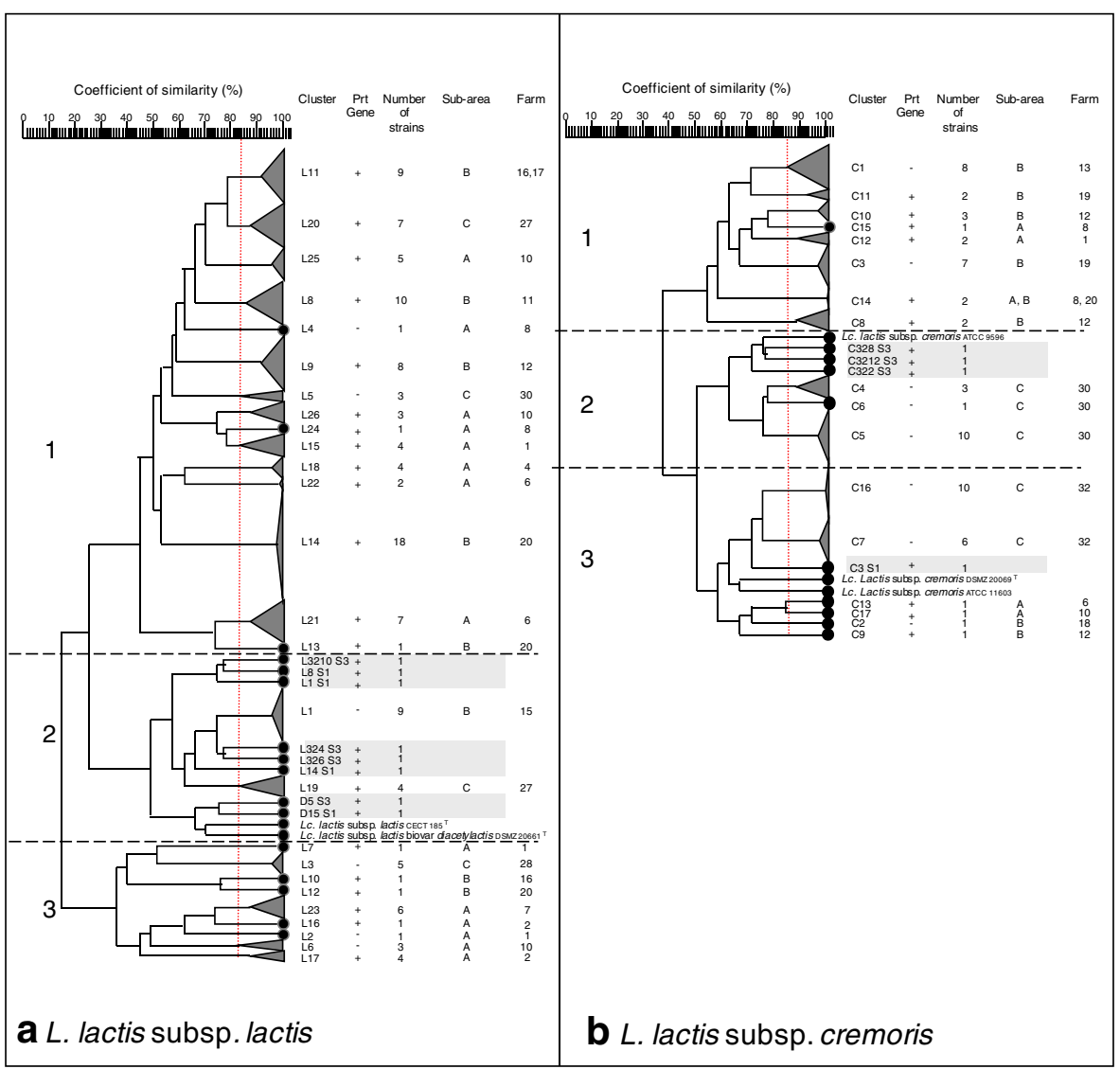

Fig. 2 Clustering of 180 wild $L$. lactis strains from 32 from Ossau-Iraty ewe's milks samples collected in three sub-areas $A(1-10), B(11-20)$, and $C(21-32)$, and 12 commercial strains from two starters, S1 and S3 (square). Normalized Rep and Eric-PCR patterns were analyzed using Pearson's product-moment correlation coefficient and were clustered by UPGMA; a 119 wild L. lactis subsp. lactis strains, two reference strains, and eight commercial strains: four from starter S1 and four from starter S3 (see Table 1); b 61 wild L. lactis subsp. cremoris strains, three reference strains, and four commercial strains: one from starter S1 and three from starter S3 (see Table 1)

Among the 26 L. lactis subsp. lactis profiles (Fig. 2a), only eight strains were represented by one strain while 2 to 18 strains were grouped at a similarity level of between 85 and $98 \%$. Three main clusters appeared with a similarity coefficient below $25 \%$. Clusters 1 and 3 only grouped autochthonous strains. Cluster 2 was comprised of all the commercial and reference strains. Only two profiles (L1, L19), represented by 13 autochthonous $L$. lactis subsp. lactis, were present in this cluster. They grouped with some commercial strains at similarity coefficients of between 62 and $75 \%$.

Among the 17 L. lactis subsp. cremoris profiles (Fig. 2b), six were represented by only one strain while the others included two to 10 isolates exhibiting similarity coefficients between 85 and $98 \%$. The dendrogram shows three main clusters with a similarity coefficient of about $35 \%$. Nine profiles represented by 34 autochthonous L. lactis subsp. cremoris were present in clusters 2 and 3. They grouped with some commercial strains with similarity coefficients below $65 \%$. Cluster 1 only grouped autochthonous strains. With the exception of strain C3 from 
commercial starter S1 which was in cluster 3, the rest of the commercial strains were located in cluster 2 .

Genotypic profile diversity was higher for the autochthonous wild strains than for the commercial ones, as observed in others studies (Corroler et al. 1998; Sánchez et al. 2000). Intra-subspecies diversity calculated from number of genotypes/number of isolates belonging to each subspecies was slightly greater for the cremoris genotype (28\%) than for the lactis genotype (22\%), as observed by Gaya et al. (1999) in fresh ewe's cheeses. Conversely, Corroler et al. (1998) showed a greater diversity for the lactis genotype isolated from raw cow's milk.

\subsection{Geographic distribution of L. lactis}

L. lactis subsp. lactis strains were scarce in the C sub-area (38.8\%) compared to the A $(87.8 \%)$ and $\mathrm{B}(69.5 \%)$ sub-areas while the proportion of cremoris genotype was two and three times greater than in the A and B sub-areas, respectively (Table 3). However, ANOVA did not reveal any significant relationship between the percentage of the two subspecies and the origin of the milk samples. This finding agrees with the observations published by Oneca et al. (2003) on wild Lactobacillus plantarum populations of raw milks produced in the Roncal PDO area but disagrees with those of Corroler et al. (1998) who reported that $80 \%$ of isolates from the Bocage Falaisien area in Normandy were members of subsp. lactis genotype, while $70 \%$ of the Bessin isolates were members of subsp. cremoris genotype, farm of origin being probably more significant than area.

Although L. lactis mean levels were similar in the B and C sub-areas, the C subarea had the fewest milks containing L. lactis strains, though it is also the sub-area where $75 \%$ of the milk samples had the highest levels of L. lactis. Indeed, $75 \%$ of the milk samples contained between 3.0 and $4.5 \log _{10}$ cfu.mL ${ }^{-1}$, whereas levels were about $1 \log _{10}$ lower in the other two sub-areas (Table 3 ).

Each of the 20 milk samples containing L. lactis included one to four distinct strains (Fig. 2a, b). Each profile corresponded to one farm except in the clusters L11 and C14. Greater strain diversity (number of L. lactis profiles/total number of L. lactis isolates) was found in sub-area A (38.8\%) than in B (19.5\%) or C (18.4\%; Table 3).

\subsection{Technological characterization}

\subsubsection{Proteolytic ability assessment}

The cell envelope proteinase gene (Prt) was detected in $29(67 \%)$ out of the 43 representative autochthonous strains: 20 L. lactis subsp. lactis and nine L. lactis subsp. cremoris. The proportion of $\mathrm{Prt}^{-}$strains belonging to the cremoris genotype (8/ 17) was twice as high (47\%) as for the lactis genotype $(6 / 26 ; 23 \%)$. All the L. lactis commercial strains were $\mathrm{Prt}^{+}$.

\subsubsection{Acidifying activity}

The initial mean $\mathrm{pH}$ value of the ewe's milk was $6.70 \pm 0.02 \mathrm{U}$. Table 4 indicates the $\Delta$ $\mathrm{pH}_{24 \mathrm{~h}}$ and the $\Delta \mathrm{pH}(\mathrm{pH} n$ step $-\mathrm{pH} n+1$ step) obtained after each step of the thermal gradient of Ossau-Iraty cheese-making as defined in Fig. 1 for the 43 indigenous $L$. 
Table 4 Mean \pm standard deviation (2 measurements for each strain) of the $\Delta \mathrm{pH}$ caused by indigenous $\mathrm{Prt}^{+}$and $\mathrm{Prt}^{-}$L. lactis strains (OI) and by the S1 and S3 commercial strains at the end of each step (see Fig. 1) of the 24-hours incubation simulating the thermal gradient of Ossau-Iraty cheese manufacture

\begin{tabular}{llllll}
\hline \multicolumn{3}{l}{ Strains origin } & & & \\
\cline { 2 - 5 } & OI & & $\mathrm{S} 1$ & $\mathrm{~S} 3$ & $P$ \\
\hline Prt gene & $\operatorname{Prt}^{-}(n=14)$ & $\operatorname{Prt}^{+}(\mathrm{n}=29)$ & $\operatorname{Prt}^{+}(n=5)$ & $\operatorname{Prt}^{+}(n=7)$ & \\
Step 1 $\left(\Delta \mathrm{pH}_{0 \mathrm{~h}-1.6 \mathrm{~h}}\right)$ & $0.02 \pm 0.02$ & $0.01 \pm 0.02$ & $0.01 \pm 0.02$ & $0.02 \pm 0.00$ & $\mathrm{NS}$ \\
Step 2 $\left(\Delta \mathrm{pH}_{1.6 \mathrm{~h}-2.3 \mathrm{~h}}\right)$ & $0.02 \pm 0.02^{\mathrm{a}}$ & $0.10 \pm 0.06^{\mathrm{b}}$ & $0.09 \pm 0.05^{\mathrm{b}}$ & $0.09 \pm 0.08^{\mathrm{b}}$ & $* * *$ \\
Step 3 $\left(\Delta \mathrm{pH}_{2.3 \mathrm{~h}-3.1 \mathrm{~h}}\right)$ & $0.07 \pm 0.00^{\mathrm{a}}$ & $0.16 \pm 0.00^{\mathrm{b}}$ & $0.22 \pm 0.00^{\mathrm{b}}$ & $0.14 \pm 0.01^{\mathrm{b}}$ & $* * *$ \\
Step 4 $\left(\Delta \mathrm{pH}_{3.1 \mathrm{~h}-7.1 \mathrm{~h}}\right)$ & $0.28 \pm 0.12^{\mathrm{a}}$ & $1.11 \pm 0.43^{\mathrm{b}}$ & $0.88 \pm 0.56^{\mathrm{b}}$ & $0.84 \pm 0.67^{\mathrm{b}}$ & $* * *$ \\
Step 5 $\left(\Delta \mathrm{pH}_{7.1 \mathrm{~h}-24 \mathrm{H}}\right)$ & $0.51 \pm 0.15$ & $0.54 \pm 0.31$ & $0.60 \pm 0.73$ & $0.57 \pm 0.44$ & $\mathrm{NS}$ \\
$\Delta \mathrm{pH}_{0 \mathrm{~h}-24 \mathrm{~h}}$ & $1.06 \pm 0.19^{\mathrm{a}}$ & $2.18 \pm 0.42^{\mathrm{b}}$ & $1.94 \pm 0.67^{\mathrm{b}}$ & $1.89 \pm 0.86^{\mathrm{b}}$ & $* * *$ \\
\hline
\end{tabular}

Prt : Protease gene; Prt $^{-}$: absence; Prt $^{+}$: presence

Different letters in the same row indicate significant differences between the average values $N S$ not significant; $* * * P<0.001$

lactis strains grouped according the presence of Prt gene and the 12 commercial strains according to the starter type (S1 or S3).

Regarding $\Delta \mathrm{pH}_{24 \mathrm{~h}}$ values, the $\mathrm{Prt}^{+}$strains were significantly more acidifying $(p<$ 0.001 ) than $\operatorname{Prt}^{-}$strains (Table 4). The indigenous $\operatorname{Prt}^{+}$strains led to a $\Delta \mathrm{pH}_{24 \mathrm{~h}}$ twofold higher than the $\mathrm{Prt}^{-}$strains, probably because there is a good correlation between acidifying and proteolytic activities as observed by Bruinenberg et al. (1992). In our study, only the presence of the cell envelope proteinase gene was investigated, not its expression or its expression level.

The highest $\Delta \mathrm{pH}$ was observed at the end of the step 4 (Table 4), after around $7 \mathrm{~h}$ of incubation, for all the $\mathrm{Prt}^{+}$strains, when the temperature was favorable (below $37^{\circ} \mathrm{C}$ ) to the growth of lactococci, as observed by Pérez-Elortondo et al. (1993) during Idiazábal cheese-making, which is technologically similar to Ossau-Iraty cheese. The $\Delta \mathrm{pH}$ caused by the Prt $^{-}$strains group at the end of the step 5 was twice as high than at the end of the step 4 (Table 4). In our study, the $\mathrm{Prt}^{+}$strains were significantly $(p<0.001)$ differentiated from Prt $^{-}$strains at the end of the steps 2, 3, and 4. At the end of the step 4 , the $\Delta \mathrm{pH}$ caused by the $\mathrm{Prt}^{+}$strains was three to four times greater than the decrease due to $\mathrm{Prt}^{-}$strains. Moreover, the decrease in $\mathrm{pH}$ during this thermal gradient cycle showed that a temperature of $40{ }^{\circ} \mathrm{C}$ (step 2) did not prevent expression of the acidifying activity of the tested L. lactis strains, as also observed by Jeanson et al. (2003). No significant differentiation was observed between the indigenous and commercial $\mathrm{Prt}^{+}$strains. The increase in standard deviation throughout the cheesemaking steps demonstrates the diversity existing within each strain group, especially when the temperature decreased from 37 to $28{ }^{\circ} \mathrm{C}$ (step 4). Under temperature conditions similar to those of non-cooked (Casalta et al. 1995) and cooked (Jeanson et al. 2003) cheese, the wild L. lactis strains also exhibited a wide diversity of acidifying activity, showing that they differed in their temperature sensitivity. The most acidifying strains belonged to the L. lactis subsp. lactis genotype (data not 
shown) but some strains belonging to the cremoris genotype were also good acidification agents $\left(\Delta \mathrm{pH}_{24 \mathrm{~h}}>2\right)$. Acidifying capacity is more strain dependent than subspecies dependent, as shown by Sánchez et al. (2000). Unlike the results of Mannu et al. (2000), in this study no correlation was established between strain genotypic profiles and acidifying activity. However, those authors did not use the same genotypic methods as in this study to distinguish between strains.

\subsubsection{Lysogeny and phage sensitivity}

Lysogeny and phage sensitivity as employed by Ward et al. (2004) to characterize a group of closely related lactococcal strains, and proved to be the best criteria for distinguishing the commercial and autochthonous strains and to characterize a group of closely related lactococcal strains.

Table 5 Pattern of lysogeny and phage sensitivity among wild (OI) and commercial (S1, S3) Lactococcus lactis strains

\begin{tabular}{|c|c|c|c|c|}
\hline & & \multicolumn{3}{|l|}{ Strain origin } \\
\hline & & OI & S1 & S3 \\
\hline \multirow[t]{7}{*}{ Collection phages } & $\mathrm{c} 2$ & $\mathrm{C} 12, \mathrm{~L} 25$ & & \\
\hline & P335 & L26 & & $\mathrm{C} 328$ \\
\hline & 971 & L18, L20 & L14 & \\
\hline & 973 & $\mathrm{C} 2$ & & L324 \\
\hline & 974 & L2, L5, L17 & & L324, L326 \\
\hline & 122 & $\begin{array}{l}\text { C3, C5, C12, L2, L5, L6, } \\
\text { L9, L10, L11, L13, L18, } \\
\text { L21, L23 }\end{array}$ & & \\
\hline & 134 & $\mathrm{C} 2, \mathrm{C} 5, \mathrm{C} 12, \mathrm{C} 13, \mathrm{~L} 5$ & & \\
\hline \multirow[t]{13}{*}{ Wheys } & W1 & L26 & D15 & $\mathrm{C} 328$ \\
\hline & W2 & & & $\mathrm{C} 328$ \\
\hline & W4 & & & D5 \\
\hline & W5 & & & $\underline{\mathrm{D} 5}$ \\
\hline & W6 & & & $\mathrm{C} 328, \mathrm{C} 3212$ \\
\hline & W7 & & & $\underline{\mathrm{C} 328}, \mathrm{C} 3212$ \\
\hline & W8 & & & D5 \\
\hline & W9 & & & $\overline{\mathrm{C} 328}$ \\
\hline & W11 & & & $\mathrm{C} 328$ \\
\hline & W14 & & & $\underline{\mathrm{D} 5}$ \\
\hline & W16 & L11 & & \\
\hline & W20 & & & $\begin{array}{l}\mathrm{C} 322, \mathrm{C} 328, \mathrm{C} 3212, \\
\mathrm{~L} 3210, \underline{\mathrm{D} 5}\end{array}$ \\
\hline & W21 & & D15 & C3212, L3210 \\
\hline
\end{tabular}

Lysogenic strains were underlined

OI: Ossau-Iraty, S1 and S3: commercial starters, C: L. lactis subsp. cremoris genotype, L: L. lactis subsp. lactis genotype, D: L. lactis subsp. lactis biovar. diacetylactis genotype 
The lysogenic strains were: among the indigenous strains, one L. lactis subsp. lactis strain (OI L19; Fig. 2a) and four L. lactis subsp. cremoris strains (OI C4, C7, C11, and $\mathrm{C} 16$; Fig. 2b) and among the commercial strains, one L. lactis subsp. lactis genotype (S1 L1), one L. lactis subsp. cremoris genotype (S3 C328), and two L. lactis subsp. lactis biovar. diacetylactis (S1 D15 and S3 D5; Table 5). The proportion of positive PCR P335 phage amplification was greater $(16.4 \%)$ in wild L. lactis from Cabrales cheese (Martín et al. 2006). The presence of lysogenic strains in commercial starters has been shown a long time ago (Reiter and Kirikova 1976). Ayad et al. (2000) also showed that most commercial strains were lysogenic, in contrast to indigenous strains.

Seven collection phages out of the 23 tested and 13 wheys out of the 21 tested caused lysis plaques (Table 5). The phagic sensitivity of the commercial and autochthonous strains was inversely correlated with the origin of the tested phages. Indeed, $60 \%$ of the commercial strains were sensitive to the phages from wheys collected from dairies using these commercial strains, compared to only $5 \%$ of the autochthonous strains. Conversely, around $50 \%$ of the autochthonous strains were sensitive to one or several collection phages compared to $33 \%$ for the commercial strains. These results agree with those obtained by Ayad et al. (2000) who showed that autochthonous strains of $L$. lactis were particularly resistant to the phages from local wheys and therefore of great interest for manufacturing a specific starter for cheese-making. The sensitivity of commercial strains to phages from dairy wheys has also been noted by De Godoy Oriani and Yokoya (2004).

\subsubsection{Compatibility of strains}

Among the 171 tested combinations, those implicating the OI L12 strain involved an abrupt stop of the $\mathrm{pH}$ decrease after approximately $2 \mathrm{~h}$ of incubation (Fig. 3), compared to the acidification curve observed with each individual strain The other combinations (data no shown) did not show any incompatibility The reported percentage of

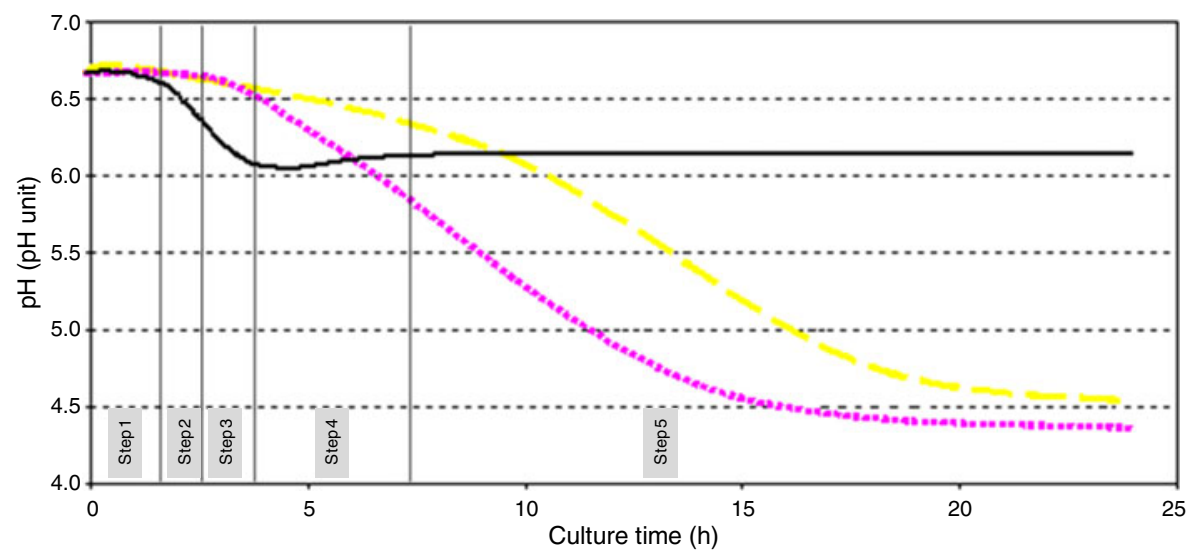

Fig. 3 pH kinetics of some L. lactis strains in reconstituted and pasteurized ewe's milk culture under the OssauIraty cheese thermal gradient (see Fig. 1). (- - -) pH kinetics of OI L12 strain; (- - ) pH kinetics of OI L7 strain; (-) pH kinetics of the two strains in combination. The curves are averaged from the duplicates of each culture 
strains (2.3\% in this study) expressing antimicrobial activity varies between studies: Ayad et al. (2004) observed that $47 \%$ of wild strains of L. lactis expressed antimicrobial activity against strains belonging to the same species whereas Sánchez et al. (2000) found no incompatibility. It is noteworthy that if an antimicrobial compound was produced, it caused the L12 acidifying activity to stop at the same time.

\section{Conclusions}

This study gives a first overview of the quantitative, genotypic, and technological variability of indigenous strains of $L$. lactis from ewes' milk samples produced in the Ossau-Iraty cheese area. Strains of L. lactis were not always detected in the ewe's milk samples. However, when they were present, they displayed a wide genotypic diversity which seemed to be strongly dependent on the farm of origin. This suggests that it would be useful to study how the farm dairy environment and stock husbandry practices and conditions favor the presence and conservation of this microbiota.

The results also show that the L. lactis populations present in Ossau-Iraty ewe's milk have a high technological potential. Since the discrepancy between the phenotypic and the genotypic characteristics of the two subspecies lactis and cremoris has been reported (Corroler et al. 1998), identification based on the classical distinction criteria will be checked in a forthcoming study to ascribe the "cremoris" or "lactis" phenotype to the genotypic wild strains of L. lactis. Indeed, a phenotypic L. lactis subsp. lactis showing a L. lactis subsp. cremoris genotype and inversely a phenotypic L. lactis subsp. cremoris showing a L. lactis subsp. lactis genotype have been reported (Fernández et al. 2011). Phenotypic differences between genotypically similar strains of L. lactis have also been found, probably linked to differences in enzymatic expression (de la Plaza et al. 2006).

This preliminary study of $L$. lactis microbiota revealed its complexity and suggests that a deeper knowledge is needed to select strains with the best properties for use in starter cultures in the manufacture of Ossau-Iraty cheese and to understand the impact of this microbiota on cheese characteristics.

Acknowledgments This work was financially supported by the Aquitaine Regional Council, the Pyrénées Atlantiques Council, ONILAIT (Paris, France), the French State (FNADT), and the European Commission (Leader II and Interreg IIIA programs). The authors would like to thank T. Janzen (Christian Hansen, Hoersholm, Denmark), E. Suárez, and C. Madera (Oviedo University, Spain) for supplying the phages and the producers from whom the milk samples were taken.

\section{References}

Ayad EHE, Verheul A, Wouters JTM, Smit G (2000) Application of wild starter cultures for flavor development in pilot plant cheese making. Int Dairy J 10:169-179

Ayad EHE, Nashat S, El-adek N, Metwaly M, El-Soda M (2004) Selection of wild lactic acid bacteria isolated from traditional Egyptian dairy products according to production and technological criteria. Food Microbiol 21:715-725

Barakat RK, Griffiths MW, Harris LJ (2000) Isolation and characterization of Carnobacterium, Lactococcus and Enterococcus spp. from cooked, modified atmosphere packaged, refrigerated, poultry meat. Int J Food Microbiol 62:83-94 
Beimfohr C, Ludwig W, Schleifer KH (1997) Rapid genotypic differentiation of Lactococcus lactis subspecies and biovar. Syst Appl Microbiol 20:216-221

Berthier F, Beuvier E, Dasen A, Grappin R (2001) Origin and diversity of mesophilic lactobacilli in Comté cheese, as revealed by PCR with repetitive and species-specific primers. Int Dairy J 11:293-295

Bruinenberg PG, Vos P, de Vos WM (1992) Proteinase overproduction in Lactococcus lactis strains: regulation and effect on growth and acidification in milk. Appl Env Microbiol 58:78-84

Callon C, Millet L, Montel MC (2004) Diversity of lactic acid bacteria isolated from AOC Salers cheese. J Dairy Res 71:231-244

Casalta E, Montel MC (2008) Safety assessment of dairy microorganisms: the Lactococcus genus. Int J Food Microbiol 126:271-273

Casalta E, Noël Y, Le Bars D, Carré C, Achilleos C, Maroselli MX (2001) Caractérisation du fromage Bastelicaccia. Lait 81:529-546

Casalta E, Vassal Y, Desmazeaud MJ, Casabianca F (1995) Comparaison de l'activité acidifante des souches de Lactococcus lactis isolées de lait et de fromages de Corse. Leben Wissen Technol 28:291-299

Corroler D, Mangin I, Desmasures N, Guéguen M (1998) An ecological study of lactococci isolated from raw milk in the Camembert cheese Registered Designation of Origin area. Appl Env Microbiol 64:4729-4735

de La Plaza M, Rodriguez A, Fernandez de Palencia P, Martinez-Cuseta MC, Pelaez C, Requena T (2006) Discrepancies between the phenotypic and genotypic characterization of Lactococcus lactis cheese isolates. Lett Appl Microbiol 43:637-644

de Godoy Oriani MR, Yokoya F (2004) Lactococcus bacteriophages isolated from whey and their effects on commercials lactic starters. Braz Arch Biol Technol 47:559-568

Depouilly A, Dufrene F, Beuvier E, Berthier F (2004) Genotypic characterization of the dynamics of the lactic acid bacterial population of Comté cheese. Lait 84:155-167

Desmasures N, Mangin I, Corroler D, Guéguen M (1998) Characterization of lactococci isolated from milk produced in the Camembert region of Normandy. J Appl Microbiol 85:999-1005

Fernández E, Alegría A, Delgado S, Martín MC, Mayo B (2011) Comparative phenotypic and molecular genetic profiling of wild Lactococcus lactis subsp. lactis strains of the L. lactis subsp. lactis and $L$. lactis subsp. cremoris genotypes isolated from starter-free cheeses made of raw milk. Appl Env Microbiol 77:5324-5335

Feutry F, Oneca M, Berthier F, Torre P (2011) Biodiversity of lactic acid bacteria in raw ewe's milk PDO Ossau-Iraty cheeses made with different starters. Food Microbiol 29:33-42

Franciosi E, Settani L, Cavazza A, Poznanski E (2009) Biodiversity and technological potential of wild lactic acid bacteria from raw cow's milk. Int Dairy J 19:3-11

Gaya P, Babin M, Medina M, Nuñez M (1999) Diversity among lactococci isolated from ewe's raw milk cheese. J Appl Microbiol 87:849-855

IDF (International Dairy Federation) (1996) Preparation of samples and dilutions for microbiological examination. Standard 122C. Brussels. Int Dairy Fed.

Jeanson S, Berthier F, Grappin R, Beuvier E (2003) Heat resistance of wild Lactococcus lactis strains under a thermal gradient of cooked cheese, in milk and in mini-cheeses. Lait 83:1-16

Klijn N, Weerkamp AH, de Vos WM (1995) Detection and characterization of lactose-utilizing Lactococcus spp. in natural ecosystems. Appl Env Microbiol 61:788-792

Labrie S, Moineau S (2000) Multiplex PCR for detection and identifiaction of Lactococcal bacteriophages. Appl Env Microbiol 66:987-994

Lafarge V, Ogier JC, Girard V, Maladen V, Leveau JY, Gruss A, Delacroix-Buchet A (2004) Raw cow milk bacterial population shifts attributable to refrigeration. App Env Microbiol 70:5644-5660

Mannu L, Paba A, Pes M, Scintu MF (2000) Genotypic and phenotypic heterogeneity among lactococci isolated from traditional Pecorino Sardo cheese. J Appl Microbiol 89:191-197

Martín MC, Ladero V, Alvarez MA (2006) PCR identification of lysogenic Lactococcus lactis strains. Journal of Consumer Protection and Food Safety 1:121-124

Medina R, Katz M, Gonzalez S, Oliver G (2001) Characterization of the lactic acid bacteria in ewe's milk and cheese from Northwest Argentina. J Food Prot 64:559-563

Nieto-Arribas P, Seseña S, Poveda JM, Palop L, Cabezas L (2009) Genotypic and technological characterization of Lactococcus lactis isolates involved in processing of artisanal Manchego cheese. J Appl Microbiol 107:1505-1517

Oneca M, Irigoyen A, Ortigosa M, Torre P (2003) PCR and RAPD identification of L. plantarum strains isolated from ovine milk and cheese. Geographical distribution of strains. FEMS Microbiol Lett 227:271-277

Pérez-Elortondo FJ, Albisu M, Barcina Y (1993) Changes in the microflora of Idiazábal cheese with the addition of commercial lactic starters. Aust J Dairy Technol 48:10-14 
Reiter B, Kirikova M (1976) The isolation of a lysogenic strains from a multiple strains starter culture. J Soc Dairy Technol 29:221-225

Sánchez MM, Delgado T, Alonso L, Mayo B (2000) Phenotypic and genetic characterization of a selected set of Lactococcus lactis strains isolated from a starter-free farmhouse cheese. Food Microbiol 17:449-460

Taïbi A, Dabour N, Lamoureux M, Roy D, La Pointe G (2010) Evaluation of the genetic polymorphism among Lactococcus lactis subsp. cremoris strains using comparative genomic hybridization and multilocus sequence analysis. Int J Food Microbiol 144:20-28

Terzaghi BE, Sandine WE (1975) Improved medium for lactic streptococci and their bacteriophages. Appl Microbiol 29:807-813

Versalovic J, Koeuth T, Lupski JR (1991) Distribution of repetitive DNA sequences in eubacteria and application to fingerprinting of bacterial genomes. Nucleic Acids Res 24:6823-6831

Ward LJH, Heap HA, Kelly WJ (2004) Characterization of closely related lactococcal starter strains which show differing patterns of bacteriophage sensitivity. J Appl Microbiol 96:144-148 